\title{
Twenty-Eight-Day Repeated-Dose Toxicity Studies for Detection of Weak Endocrine Disrupting Effects of Nonylphenol and Atrazine in Female Rats
}

\author{
Sunao Aso ${ }^{1}$, Makiko Anai ${ }^{1}$, Shyuji Noda ${ }^{1}$, Nobuya Imatanaka ${ }^{1}$, Kanji Yamasaki ${ }^{1}$, and Akihiko \\ Maekawa ${ }^{2}$ \\ ${ }^{1}$ Chemicals Assessment Center, Chemicals Evaluation and Research Institute and ${ }^{2}$ Department of Pathology, Sasaki Institute
}

\begin{abstract}
To assess the risk evaluation of endocrine disrupting chemicals with weak estrogenic or anti-estrogenic effects in mammals, the suitability of 28 -day repeated dosing test and the strain difference were investigated in adult female rats. In the study, 60 and $250(150) \mathrm{mg} / \mathrm{kg} /$ day of nonylphenol and 5 and $50 \mathrm{mg} / \mathrm{kg} /$ day of atrazine were dosed to female SD, F344, and Donryu rats for 28 days. Abnormal estrous cyclicity was observed in both groups of SD rats given nonylphenol, in the highdose nonylphenol and atrazine F344 rats, and in both groups of Donryu rats receiving the test compounds. A slight tendency for increase in numbers of uterine BrdU-positive cells was observed in F344 rats given high-dose nonylphenol, and elevation was noted in one animal each which showed persistent estrus in the groups of Donryu rats given atrazine. Organ weight, necropsy and histopathological findings did not point to any effects of these chemicals on the endocrine or reproductive systems except for ovarian atrophy in the atrazine treated Donryu rats with persistent estrus. These results indicate that severe morphological effects might not be induced in female reproductive organs of adult rats by short-term exposure to these chemicals, unless very high doses are given. Vaginal smear may be the most sensitive parameter for detection of estrogenic or anti-estrogenic effects of chemicals, when normal cycling animals are used for the study. (J Toxicol Pathol 2000; 13: 13 20)

Key words : Nonylphenol, atrazine, endocrine disrupters, 28-day repeated study, rat
\end{abstract}

\section{Introduction}

Recently, a number of chemicals have been identified which disrupt normal endocrine functions and misgivings about their existence are rapidly rising worldwide, although the actual hazards posed to man and wildlife remain unclear $^{1,2}$. To detect the estrogenic or anti-estrogenic activity of environmental chemicals, the uterotropic assay using immature or ovariectomized rats has been proposed as one of the screening test systems by OECD. On the other hand, for assessment of toxic effects of environmental chemicals, a short-term screening test protocol has been proposed as OECD Test Guideline (TG) 407: A 28-day repeated toxicity test protocol using adult rats as a rule. In addition, for endocrine disrupting chemicals, OECD has recently proposed a new screening test protocol, the enhanced OECD TG 407 protocol.

Nonylphenol, a surfactant used in the production of laboratory plasticware, and has been reported to have estrogenic activity ${ }^{3,4}$. Atrazine is a chloro-s-triazine herbicide that has been widely employed for agricultural applications for many years and has anti-estrogenic activity ${ }^{5-7}$. However, the endocrine disrupting potential of these two compounds is relatively weak ${ }^{7-10}$, and their toxicity data with adult female rats with normal estrous cycle are very few.

On the other hand, estrogens are of essential importance for development of uterine endometrial adenocarcinomas and mammary carcinomas in mammals. In rats, however, spon-

Received : 29 September 1999, Accepted: 15 December 1999 Mailing address: S. Aso, Chemicals Assessment Center, Chemicals Evaluation and Research Institute, 3-88 Ishii-cho, Hita-shi, Oita 8770016, Tel. 0973-24-7211, Fax 0973-22-9800 taneous occurrence of endometrial adenocarcinomas is generally very rare, and estrogen alone can not induce carcinomas $^{11}$, although it acts as a complete carcinogen in mice $^{11,12}$. SD and F344 Fischer rats are the strains most widely used in toxicity study including carcinogenicity studies throughout the world. However, this may present problems because their spontaneous occurrence of endometrial adenocarcinomas is very low ${ }^{13}$. The Donryu rat, an inbred Japanese albino rat, is known to be a high incidence strain for spontaneous development of endometrial adenocarcinomas, associated with a hormonal imbalance ${ }^{14}$. Donryu rats are more sensitive to carcinogens/hormones than F344 rats with regard to uterine carcinogenesis ${ }^{11}$. Straindifferences have been reported between F344 and SD rats for example concerning the induction incidence of mammary tumors by the endocrine disrupter, atrazine ${ }^{15}$. These strain differences might effect on the sensitivity of screening tests to detect endocrine disrupting activity of chemicals, because many toxicokinetic data revealed strain differences in the biological effects of chemicals in rats ${ }^{16}$.

To assess the risk evaluation of endocrine disruption chemicals with weak estrogenic or anti-estrogenic effects in mammals, 28-day repeated toxicity and strain difference of nonylphenol and atrazine were investigated in adult female rats.

\section{Materials and Methods}

\section{Chemicals}

Nonylphenol (mixed isomer, Lot no. JI208, purity: 99.6\%) was provided by Mitsui Chemical Co. Ltd. (Tokyo), and atrazine $\left(\mathrm{C}_{8} \mathrm{H}_{14} \mathrm{ClN}_{5}\right.$, Lot no. MSF9593, purity: $\left.98.7 \%\right)$ 
was purchased from Wako Pure Chemical Industries Ltd. (Osaka).

\section{Animals and housing conditions}

Ten-week-old female Crj : CD (SD) IGS, F344/DuCrj (Fischer), and $\mathrm{Crj}$ : Donryu rats were purchased from Charles River Japan, Inc. (Yokohama). After quarantine and acclimation for 2 weeks, only healthy animals showing favorable body weight gain, good general condition, and normal estrous cycles were used for the study. Groups of six animals were allocated using body weight-stratified randomization.

The animals were housed, one/cage in an animal room in which the temperature, relative humidity, and ventilation rate were set at $23 \pm 2^{\circ} \mathrm{C}, 55 \pm 10 \%$, and $10-15$ times $/ \mathrm{h}$, respectively, and allowed free access to pelleted diet (MF, Oriental Yeast Co., Ltd., Tokyo) and tap water. All experiments in the present study followed the guidelines for animal experimentation of the Japanese Association for Laboratory Animal Science ${ }^{17}$.

\section{Experimental design}

Nonylphenol was dissolved in olive oil, and atrazine was suspended in $0.5 \%$ sodium carboxy-methyl-cellulose. The rats of each strain were dosed at levels of 0,60 or 250 $\mathrm{mg} / \mathrm{kg} /$ day nonylphenol and 0,5 or $50 \mathrm{mg} / \mathrm{kg} /$ day atrazine by stomach tube for 28 days or till the day on which their vaginal smear indicated diestrus after 28 days. The $250 \mathrm{mg}$ / $\mathrm{kg}$ dose of nonylphenol was changed to $150 \mathrm{mg} / \mathrm{kg}$ at 5 days because the general condition of rats of all SD and F344 strains had markedly deteriorated.

The animals were observed for condition and behavior on a daily base during the dosing period. Body weights were measured at $1,8,15,22$, and 28 days of dosing and just before necropsy. All animals were examined for their estrous cycles every day during the dosing period, and necropsied on day 28 when their estrous cycle showed diestrus or the day showing diestrus after 28 days. One Donryu rat each in the 5 and $50 \mathrm{mg} / \mathrm{kg}$ of atrazine treated groups with vaginal smears indicating persistent estrus was sacrificed on day 44 , these animals being given the chemical for 43 days. The animals which showed estrus for more than three days continuously were designated to be in persistent estrus. Wet organ weights of the hypophysis, liver, adrenals, kidneys, ovaries, and uterus were determined. In addition to the organs mentioned above, the vagina and mammary gland were fixed in neutralized buffered $10 \%$ formalin, processed routinely, and examined histopathologically. To examine the number of cells undergoing division, based on S-phase incorporation of marker, all animals were injected with a single shot of 5 bromo-2'-deoxyurdine (BrdU, $40 \mathrm{mg} / \mathrm{kg}$ of body weight, Sigma Chemical Co., USA) intraperitoneally $2 \mathrm{hr}$ before necropsy, and sections of uterus were incubated with BrdU antibody (Dako Japan, Kyoto) using the $\mathrm{ABC}$ method, as described previously ${ }^{18}$. The numbers of BrdU-positive nuclei per 1,000 nuclei in the luminal epithelial cells were counted per animal.

\section{Statistical analysis}

With regard to body and organ weights, and numbers of $\mathrm{S}$-phase cells, one-way analysis of variance was used for testing the significance of intergroup differences.

When significance was revealed in this analysis, the Dunnett's multiple comparison test ${ }^{19}$ was employed.

\section{Results}

\section{General condition}

In the nonylphenol treated SD rats of the $250 \mathrm{mg} / \mathrm{kg}$ group, decrease of spontaneous locomotion and respiratory rate, nasal bleeding, staining around the nose and mouth, lid closure, soft stools, moisture at the lower abdomen, and increased salivation were observed. Staining around the nose and mouth and moisture at the lower abdomen were also observed in the $60 \mathrm{mg} / \mathrm{kg}$ group. Decrease of spontaneous locomotion and respiratory rate, lid closure, soft stools, nasal bleeding, staining around the nose and mouth, moisture at the lower abdomen, decreased stool volume, unkempt hair, crouching position, reddish tears, and mucous stool were also observed in F344 rats of the $250 \mathrm{mg} / \mathrm{kg}$ nonylphenol group. These findings were almost recovered after 5 days when the $250 \mathrm{mg} / \mathrm{kg}$ dose was diminished to $150 \mathrm{mg} / \mathrm{kg}$, although one $\mathrm{SD}$ rat in the $250(150) \mathrm{mg} / \mathrm{kg}$ group died from an accident on day 9 of dosing. In contrast, in Donryu rats receiving the high-dose, only reddish tears and increased salivation were observed. After change of dosage, these changes detected in high dose groups of every three strain recovered. In the atrazine treated groups, no abnormalities of general condition were detected in SD or Donryu rats, although increased salivation was noted in F344 rats of the $50 \mathrm{mg} / \mathrm{kg}$ group.

\section{Body weights}

Body weights of animals given nonylphenol and atrazine are shown in Tables 1 and 2 . In the nonylphenol treated groups, SD and F344 rats in the high-dose group demonstrated decreased body weights on day 8 of dosing, but then recovered. No effects on Donryu rat body weight gain were apparent.

In the atrazine treated groups, F344 and Donryu but not SD rats in the $50 \mathrm{mg} / \mathrm{kg}$ group had a slight tendency for decrease of body weights on days 22 and 28 , compared to the control groups.

\section{Estrous cycle}

Data for estrous cycle abnormality in animals given nonylphenol and atrazine are summarized in Tables 3 and 4. One SD rat in the $60 \mathrm{mg} / \mathrm{kg}$ nonylphenol group showed an abnormal estrous cycle from days 6 to 9 , although this then recovered. In the $250(150) \mathrm{mg} / \mathrm{kg}$ group, 5 animals demonstrated abnormal cycles from days 5 or 7 of dosing, this recovering from day 9 in 2 cases but persisting in the remaining 3. In F344 rats, all animals in the high-dose group showed similar abnormal cycles from days 3 or 7 , with recovery from days 9 to 15 . Two of these animals showed persistent estrus continuing for 3 days. In the Donryu case, one $60 \mathrm{mg} / \mathrm{kg}$ animal showed an abnormal cycle from days 9 to 13 , and two in the $250(150) \mathrm{mg} / \mathrm{kg}$ group, one from days 5 to 15 and the other from day 26 onwards.

In the atrazine treated groups, there were no abnormalities of the estrous cycle in SD rats. One F344 rat in the 50 $\mathrm{mg} / \mathrm{kg}$ group showed persistent estrus continuing for 4 days from day 18 , but recovered after that. In Donryu rats, one animal each in the 5 and $50 \mathrm{mg} / \mathrm{kg}$ groups also demonstrated persistent estrus. In these animals, the estrous cycle stopped from day 31 or 33 , persistent estrus continuing for 14 and 12 days, respectively. 
Table 1. Body Weights of Rats Dosed with Nonylphenol for 28 Days

\begin{tabular}{|c|c|c|c|c|c|c|c|}
\hline \multirow{2}{*}{ Strain } & \multirow{2}{*}{$\begin{array}{c}\text { Doses } \\
(\mathrm{mg} / \mathrm{kg} / \text { day })\end{array}$} & \multicolumn{6}{|c|}{ Experimental days } \\
\hline & & -1 & 1 & 8 & 15 & 22 & 28 \\
\hline \multirow{3}{*}{$\mathrm{SD}$} & 0 & $\begin{array}{r}239.4 \\
+\quad 6.5\end{array}$ & $\begin{array}{r}238.4 \\
+\quad 8.1\end{array}$ & $\begin{array}{r}244.6 \\
+\quad 8.0\end{array}$ & $\begin{array}{r}247.1 \\
\pm \quad 6.2\end{array}$ & $\begin{array}{r}251.3 \\
\pm 12.0\end{array}$ & $\begin{array}{r}258.1 \\
+11.8\end{array}$ \\
\hline & 60 & $\begin{array}{r}239.0 \\
\pm \quad 9.3\end{array}$ & $\begin{array}{r}237.3 \\
\pm 10.5\end{array}$ & $\begin{array}{r}238.4 \\
+\quad 8.9\end{array}$ & $\begin{array}{r}238.8 \\
+12.4\end{array}$ & $\begin{array}{r}242.9 \\
+14.7\end{array}$ & $\begin{array}{r}250.3 \\
+15.4\end{array}$ \\
\hline & $250-150^{\mathrm{a})}$ & $\begin{array}{r}239.7 \\
\pm \quad 5.9\end{array}$ & $\begin{array}{r}236.4 \\
\pm \quad 6.3\end{array}$ & $\begin{array}{r}227.9 \\
\pm 25.2\end{array}$ & $\begin{array}{r}243.5 \\
\pm 8.3(5)^{b)}\end{array}$ & $\begin{array}{r}251.1 \\
\pm 11.2(5)\end{array}$ & $\begin{array}{l}255.6 \\
\pm \quad 9.6(5)\end{array}$ \\
\hline \multirow{3}{*}{ F344 } & 0 & $\begin{array}{r}155.4 \\
\pm \quad 7.8\end{array}$ & $\begin{array}{r}154.3 \\
\pm \quad 6.4\end{array}$ & $\begin{array}{r}155.9 \\
\pm \quad 8.9\end{array}$ & $\begin{array}{r}160.4 \\
\pm 11.1\end{array}$ & $\begin{array}{r}163.9 \\
\pm 10.4\end{array}$ & $\begin{array}{r}165.5 \\
\pm 11.3\end{array}$ \\
\hline & 60 & $\begin{array}{r}155.7 \\
+\quad 4.7\end{array}$ & $\begin{array}{r}155.6 \\
+\quad 4.0\end{array}$ & $\begin{array}{r}156.6 \\
+\quad 4.3\end{array}$ & $\begin{array}{r}161.2 \\
+\quad 4.9\end{array}$ & $\begin{array}{r}167.1 \\
+\quad 6.4\end{array}$ & $\begin{array}{r}168.9 \\
+\quad 7.9\end{array}$ \\
\hline & $250-150^{\mathrm{a})}$ & $\begin{array}{r}156.0 \\
+\quad 4.9\end{array}$ & $\begin{array}{r}154.8 \\
+\quad 4.2\end{array}$ & $\begin{array}{r}133.7 \\
+21.3\end{array}$ & $\begin{array}{r}158.9 \\
+12.2\end{array}$ & $\begin{array}{r}169.9 \\
+\quad 8.3\end{array}$ & $\begin{array}{r}174.1 \\
+\quad 7.5\end{array}$ \\
\hline \multirow{3}{*}{ Donryu } & 0 & $\begin{array}{r}264.6 \\
\pm \quad 6.1\end{array}$ & $\begin{array}{r}264.8 \\
\pm \quad 8.0\end{array}$ & $\begin{array}{r}266.9 \\
+\quad 7.0\end{array}$ & $\begin{array}{r}269.3 \\
+\quad 9.4\end{array}$ & $\begin{array}{r}273.7 \\
\pm 10.0\end{array}$ & $\begin{array}{r}281.4 \\
\pm \quad 8.2\end{array}$ \\
\hline & 60 & $\begin{array}{r}264.4 \\
\pm \quad 6.9\end{array}$ & $\begin{array}{r}264.9 \\
\pm \quad 8.4\end{array}$ & $\begin{array}{r}263.0 \\
\pm \quad 5.0\end{array}$ & $\begin{array}{r}267.8 \\
+\quad 9.3\end{array}$ & $\begin{array}{r}268.8 \\
\pm 11.5\end{array}$ & $\begin{array}{r}272.5 \\
\pm \quad 7.6\end{array}$ \\
\hline & $250-150^{\mathrm{a})}$ & $\begin{array}{r}264.3 \\
+\quad 5.5\end{array}$ & $\begin{array}{r}262.6 \\
+\quad 8.1\end{array}$ & $\begin{array}{r}260.6 \\
+\quad 9.5\end{array}$ & $\begin{array}{r}269.5 \\
+12.8\end{array}$ & $\begin{array}{r}271.6 \\
+10.9\end{array}$ & $\begin{array}{r}276.5 \\
+\quad 9.5\end{array}$ \\
\hline
\end{tabular}

Mean $(g) \pm$ S.D.

a) Dosed at a level of $250 \mathrm{mg} / \mathrm{kg}$ from days 1 to 4 of dosing and at $150 \mathrm{mg} / \mathrm{kg}$ thereafter.

b) Values in parentheses are the numbers of animals used for the calculation.

Table 2. Body Weights of Rats Dosed with Atrazine for 28 Days

\begin{tabular}{|c|c|c|c|c|c|c|c|c|c|}
\hline \multirow{2}{*}{ Strain } & \multirow{2}{*}{$\begin{array}{c}\text { Doses } \\
(\mathrm{mg} / \mathrm{kg} / \text { day })\end{array}$} & \multicolumn{8}{|c|}{ Experimental days } \\
\hline & & -1 & 1 & 8 & 15 & 22 & 28 & 36 & 43 \\
\hline \multirow{3}{*}{ SD } & 0 & $\begin{array}{r}238.4 \\
\pm 12.8\end{array}$ & $\begin{array}{r}237.5 \\
\pm 12.7\end{array}$ & $\begin{array}{r}242.2 \\
\pm 15.9\end{array}$ & $\begin{array}{r}241.5 \\
\pm 14.6\end{array}$ & $\begin{array}{r}244.5 \\
\pm 17.1\end{array}$ & $\begin{array}{r}250.1 \\
\pm 16.6\end{array}$ & & \\
\hline & 5 & $\begin{array}{r}238.2 \\
\pm \quad 6.8\end{array}$ & $\begin{array}{r}236.4 \\
\pm \quad 9.6\end{array}$ & $\begin{array}{r}243.6 \\
\pm \quad 4.9\end{array}$ & $\begin{array}{r}245.3 \\
\pm \quad 6.1\end{array}$ & $\begin{array}{r}250.9 \\
\pm 11.3\end{array}$ & $\begin{array}{r}258.3 \\
\pm 10.7\end{array}$ & & \\
\hline & 50 & $\begin{array}{r}238.4 \\
\pm \quad 8.6 \\
\end{array}$ & $\begin{array}{r}237.3 \\
\pm \quad 6.1 \\
\end{array}$ & $\begin{array}{r}238.7 \\
\pm 11.2 \\
\end{array}$ & $\begin{array}{r}242.8 \\
\pm \quad 9.4 \\
\end{array}$ & $\begin{array}{r}244.8 \\
\pm \quad 5.6 \\
\end{array}$ & $\begin{array}{r}256.6 \\
\pm \quad 7.0 \\
\end{array}$ & & \\
\hline \multirow{3}{*}{ F 344} & 0 & $\begin{array}{r}155.3 \\
+\quad 6.6\end{array}$ & $\begin{array}{r}154.4 \\
\pm \quad 6.0\end{array}$ & $\begin{array}{r}156.7 \\
\pm \quad 6.2\end{array}$ & $\begin{array}{r}162.5 \\
\pm \quad 5.7\end{array}$ & $\begin{array}{r}169.6 \\
\pm \quad 6.8\end{array}$ & $\begin{array}{r}172.2 \\
\pm \quad 6.8\end{array}$ & & \\
\hline & 5 & $\begin{array}{r}155.9 \\
\pm \quad 5.8\end{array}$ & $\begin{array}{r}154.2 \\
+\quad 6.5\end{array}$ & $\begin{array}{r}157.6 \\
+\quad 5.6\end{array}$ & $\begin{array}{r}161.6 \\
+\quad 5.9\end{array}$ & $\begin{array}{r}165.9 \\
+\quad 7.8\end{array}$ & $\begin{array}{r}170.2 \\
+\quad 9.3\end{array}$ & & \\
\hline & 50 & $\begin{array}{r}155.8 \\
\pm \quad 5.0\end{array}$ & $\begin{array}{r}154.4 \\
\pm \quad 5.2\end{array}$ & $\begin{array}{r}154.1 \\
+\quad 9.7\end{array}$ & $\begin{array}{r}158.4 \\
+\quad 8.3\end{array}$ & $\begin{array}{r}159.1 \\
+\quad 8.9\end{array}$ & $\begin{array}{r}162.7 \\
+\quad 8.4 \\
\end{array}$ & & \\
\hline \multirow{3}{*}{ Donryu } & 0 & $\begin{array}{r}264.8 \\
\pm \quad 6.5\end{array}$ & $\begin{array}{r}261.3 \\
\pm 10.2\end{array}$ & $\begin{array}{r}269.6 \\
\pm 11.1\end{array}$ & $\begin{array}{r}277.5 \\
\pm \quad 6.8\end{array}$ & $\begin{array}{r}280.6 \\
\pm 11.1\end{array}$ & $\begin{array}{r}283.6 \\
\pm \quad 9.7\end{array}$ & & \\
\hline & 5 & $\begin{array}{r}264.2 \\
\pm \quad 6.0\end{array}$ & $\begin{array}{r}265.9 \\
\pm \quad 8.9\end{array}$ & $\begin{array}{r}270.2 \\
\pm \quad 5.8\end{array}$ & $\begin{array}{r}271.8 \\
\pm \quad 9.6\end{array}$ & $\begin{array}{r}282.1 \\
\pm \quad 9.8\end{array}$ & $\begin{array}{r}283.2 \\
\pm \quad 9.7\end{array}$ & $263.5(1)^{a)}$ & $276.3(1)$ \\
\hline & 50 & $\begin{array}{r}264.4 \\
\pm \quad 7.3 \\
\end{array}$ & $\begin{array}{r}260.7 \\
\pm 10.3 \\
\end{array}$ & $\begin{array}{r}270.5 \\
\pm 14.5 \\
\end{array}$ & $\begin{array}{r}276.4 \\
\pm 23.1 \\
\end{array}$ & $\begin{array}{r}272.1 \\
\pm 17.6 \\
\end{array}$ & $\begin{array}{r}277.8 \\
\pm 18.0 \\
\end{array}$ & $273.7(1)$ & $288.3(1)$ \\
\hline
\end{tabular}

Mean $(\mathrm{g}) \pm$ S.D.

a) Values in parentheses are the numbers of animals used for the calculation.

\section{Organ weight}

Data for relative organ weights are summarized in Tables 5 and 6 . Absolute organ weights showed similar tendencies to relative organ weights (data not shown). In nonylphenol treated SD and Donryu rats, there were no abnormalities in organ weights of the uterus, adrenal, kidney, ovary, or hypophysis, although liver weights were increased with the $250(150) \mathrm{mg} / \mathrm{kg}$ dose. In F344 rats, liver, kidney, and adrenal weights were significantly increased in 250 (150) $\mathrm{mg} / \mathrm{kg}$ group. In this rat strain, significant decrease of uterine weight was also observed in the $60 \mathrm{mg} / \mathrm{kg}$ group, although there was no dose-effect relation.

In the atrazine treated groups, there were no abnormal- 
Table 3. Estrous Cycle Abnormality in Rats Dosed with Nonylphenol for 28 Days

\begin{tabular}{ccl}
\hline Strain & $\begin{array}{c}\text { Doses } \\
(\mathrm{mg} / \mathrm{kg} / \text { day })\end{array}$ & \multicolumn{1}{c}{$\begin{array}{c}\text { No. of animals } \\
\text { with abnormal cycles }\end{array}$} \\
\hline \multirow{4}{*}{ SD } & 0 & $0 / 6$ \\
& 60 & $1 / 6$ \\
& $250-150^{\text {a) }}$ & $5 / 6^{\sharp}$ \\
\hline \multirow{4}{*}{ F344 } & 0 & $0 / 6$ \\
& 60 & $0 / 6$ \\
& $250-150^{\text {a) }}$ & $6 / 6(2:$ persistent estrus for 3 days $)$ \\
\hline \multirow{4}{*}{ Donryu } & 0 & $0 / 6$ \\
& 60 & $1 / 6$ \\
& $250-150^{\text {a) }}$ & $2 / 6$
\end{tabular}

a) Dosed at a level of $250 \mathrm{mg} / \mathrm{kg}$ from days 1 to 4 of dosing and at $150 \mathrm{mg} / \mathrm{kg}$ thereafter.

* Including one animal which died.

Table 4. Estrous Cycle Abnormality in Rats Dosed with Atrazine for 28 Days

\begin{tabular}{ccl}
\hline Strain & $\begin{array}{c}\text { Doses } \\
(\mathrm{mg} / \mathrm{kg} / \text { day })\end{array}$ & \multicolumn{1}{c}{$\begin{array}{l}\text { No. of animals } \\
\text { with abnormal cycle }\end{array}$} \\
\hline \multirow{3}{*}{ SD } & 0 & $0 / 6$ \\
& 5 & $0 / 6$ \\
& 50 & $0 / 6$ \\
\hline \multirow{3}{*}{ F344 } & 0 & $0 / 6$ \\
& 5 & $0 / 6$ \\
& 50 & $1 / 6$ (persistent estrus for 4 days) \\
Donryu & 0 & $0 / 6$ \\
& 5 & $1 / 6$ (persistent estrus for 14 days) \\
& 50 & $1 / 6$ (persistent estrus for 12 days)
\end{tabular}

ities in organ weights of the uterus, adrenal, kidney, ovary, or hypophysis in any rat strain, although liver weights were increased in the $50 \mathrm{mg} / \mathrm{kg}$ groups of both SD and Donryu rats. In the latter, decrease of ovary weight was seen in one animal each showing persistent estrus in the 5 and $50 \mathrm{mg} / \mathrm{kg}$ groups (14.1 and $18.9 \mathrm{mg} / 100 \mathrm{~g}$, respectively), although there were no significant differences in mean ovarian weights between the controls and the two treated groups.

\section{Necropsy findings}

In the nonylphenol treated groups of all rat strains, no abnormalities attributable to the test chemical were found.

In the atrazine treated groups, there were also no abnormalities in SD or F344 rats, although small ovaries were found in each one animal showing persistent estrus in the 5 and $50 \mathrm{mg} / \mathrm{kg}$ groups of Donryu rats.

\section{Histopathological findings}

In the nonylphenol treated groups of all rat strains, there were no abnormalities in the uterus and ovary, the height of endometrial epithelial cells being the same in the controls and treated rats, although swelling of hepatocytes was observed in F344 rats of the 250 (150) $\mathrm{mg} / \mathrm{kg}$ group. There were also no abnormalities in the vagina, mammary gland, hypophysis, or adrenals.

In the atrazine treated groups, there were no abnormalities in the female genital organs of SD or F344 rats. In Donryu rats, however, corpora lutea were not seen in the ovaries (Fig. 1) of one animal each in the 5 and $50 \mathrm{mg} / \mathrm{kg}$ groups, the ovaries being small in size. There were no abnormalities in the uterus or vagina of all treated rats including these two animals.

\section{Mitotic cells in the uterine endothelium}

In the nonylphenol treated groups, there were no differences in numbers of BrdU-positive cells in the uterine epithelium among groups of SD and Donryu rats given 250 (150) $\mathrm{mg} / \mathrm{kg}$. However, F344 rats in the high-dose group had tendencies for slightly increased numbers of S-phase cells but the standard deviation was very large (Table 7).

In the atrazine treated SD and F344 groups, there were no significant differences. In Donryu rats, increase of BrdUpositive cells was obvious in one animal each of the 5 and 50 $\mathrm{mg} / \mathrm{kg}$ groups showing persistent estrus (89.69 and 79.32 respectively), but there was no difference at the group level, when numbers of S-phase cells were compared between the controls and both treated groups excluding one animal each showing persistent estrus (Table 8).

\section{Discussion}

In the uteropropic assay using immature or ovariectomized rats, uterine weight and luminal epithelial cell-height have been proposed to be good parameters for detection of estrogenic and anti-estrogenic effects of chemiclas ${ }^{20-22}$. It has been reported that nonylphenol exerts uterotropic effects in immature female rats dosed intraperitoneally at levels of 20 and $50 \mathrm{mg} /$ animal with a dose-dependent increase in uterine weights ${ }^{23}$, also increases the mitotic index in endometrial epithelium of ovariectomized rats dosed at levels of 1.0, 2.0, and $5.0 \mathrm{mg} /$ animal $^{3}$. In the present study, there was no tendency for dose-dependent increase of uterine weight in any strains of rats given nonylphenol, and there were also no differences in the height of uterine epithelial cells between control and treated groups of nonylphenol. In the present study, abnormal estrous cyclicity was observed in the highdose groups of SD, F344, and Donryu rats given nonylphenol, although the incidence was low in Donryu rats. This might have been due to direct effects of this chemical, because alteration in general condition and body weight was limited, at least after cessation of the $250 \mathrm{mg} / \mathrm{kg}$ dose, and abnormal cyclicity was also seen in the low-dose groups of $\mathrm{SD}$ and Donryu rats in which no or only slight changes of general condition were shown. However, these abnormal cyclicities in some animals of SD and F344 rats given the high-dose of nonylphenol were recovered after cessation of the $250 \mathrm{mg} / \mathrm{kg}$ dose. Thus, the possibility that abnormal cyclicity observed in these cases is due to indirect causes, can not be denied, because it is well known that stress induces abnormal cyclicity in rodent ${ }^{24}$. In the present study, one SD rat in the $250(150) \mathrm{mg} / \mathrm{kg}$ group died on day 9 . In this animal, broad necrosis and calcification of the cardiac muscle were histologically observed, and these findings were considered to be the cause of death. However, no similar lesion was observed in any of other rats given the same dose in this study, and also in the previous report ${ }^{25}$ by Okazaki in which dosage and treatment period of nonylphenol were almost the 
Table 5. Relative Organ Weights of Rats Dosed with Nonylphenol for 28 Days

\begin{tabular}{|c|c|c|c|c|c|}
\hline \multirow{2}{*}{ Strain } & & & \multicolumn{3}{|c|}{ Doses $(\mathrm{mg} / \mathrm{kg} /$ day $)$} \\
\hline & & & 0 & 60 & $250-150^{a)}$ \\
\hline \multirow{6}{*}{ SD } & Liver & $(\mathrm{g} / 100 \mathrm{~g})$ & $3.10 \pm 0.19$ & $2.96 \pm 0.09$ & $3.57 \pm 0.21^{* *}$ \\
\hline & Kidney & $(\mathrm{g} / 100 \mathrm{~g})$ & $0.61 \pm 0.03$ & $0.63 \pm 0.04$ & $0.63 \pm 0.06$ \\
\hline & Uterus & $(\mathrm{g} / 100 \mathrm{~g})$ & $0.21 \pm 0.05$ & $0.23 \pm 0.08$ & $0.19 \pm 0.07$ \\
\hline & Adrenal & $(\mathrm{mg} / 100 \mathrm{~g})$ & $24.6 \pm 1.6$ & $26.1 \pm 3.1$ & $26.4 \pm 2.0$ \\
\hline & Ovary & $(\mathrm{mg} / 100 \mathrm{~g})$ & $30.4 \pm 4.7$ & $31.5 \pm 4.6$ & $31.4 \pm 4.2$ \\
\hline & Hypophysis & $(\mathrm{mg} / 100 \mathrm{~g})$ & $6.0 \pm 1.1$ & $5.7 \pm 0.9$ & $5.9 \pm 0.7$ \\
\hline \multirow{6}{*}{ F344 } & Liver & $(\mathrm{g} / 100 \mathrm{~g})$ & $2.70 \pm 0.07$ & $2.97 \pm 0.08$ & $3.54 \pm 0.20^{* *}$ \\
\hline & Kidney & $(\mathrm{g} / 100 \mathrm{~g})$ & $0.66 \pm 0.02$ & $0.64 \pm 0.03$ & $0.76 \pm 0.03^{* *}$ \\
\hline & Uterus & $(\mathrm{g} / 100 \mathrm{~g})$ & $0.28 \pm 0.07$ & $0.20 \pm 0.02 * *$ & $0.23 \pm 0.03$ \\
\hline & Adrenal & $(\mathrm{mg} / 100 \mathrm{~g})$ & $27.3 \pm 3.5$ & $28.1 \pm 3.3$ & $33.7 \pm 1.1^{* *}$ \\
\hline & Ovary & $(\mathrm{mg} / 100 \mathrm{~g})$ & $32.5 \pm 3.9$ & $30.5 \pm 2.4$ & $28.5 \pm 3.1$ \\
\hline & Hypophysis & $(\mathrm{mg} / 100 \mathrm{~g})$ & $6.0 \pm 1.3$ & $6.0 \pm 0.8$ & $5.9 \pm 1.2$ \\
\hline \multirow{6}{*}{ Donryu } & Liver & $(\mathrm{g} / 100 \mathrm{~g})$ & $3.37 \pm 0.11$ & $3.46 \pm 0.29$ & $3.99 \pm 0.24^{* *}$ \\
\hline & Kidney & $(\mathrm{g} / 100 \mathrm{~g})$ & $0.60 \pm 0.04$ & $0.62 \pm 0.04$ & $0.61 \pm 0.05$ \\
\hline & Uterus & $(\mathrm{g} / 100 \mathrm{~g})$ & $0.22 \pm 0.04$ & $0.23 \pm 0.02$ & $0.23 \pm 0.07$ \\
\hline & Adrenal & $(\mathrm{mg} / 100 \mathrm{~g})$ & $25.8 \pm 2.4$ & $27.0 \pm 1.1$ & $28.8 \pm 4.9$ \\
\hline & Ovary & $(\mathrm{mg} / 100 \mathrm{~g})$ & $29.2 \pm 4.7$ & $33.4 \pm 3.6$ & $29.2 \pm 3.6$ \\
\hline & Hypophysis & $(\mathrm{mg} / 100 \mathrm{~g})$ & $4.3 \pm 0.5$ & $4.1 \pm 0.3$ & $4.8 \pm 1.2$ \\
\hline
\end{tabular}

Mean \pm S.D.

a) Dosed at a level of $250 \mathrm{mg} / \mathrm{kg}$ from days 1 to 4 and at $150 \mathrm{mg} / \mathrm{kg}$ thereafter.

** Significantly different from the control at $p<0.01$.

Table 6. Relative Organ Weights of Rats Dosed with Atrazine for 28 Days

\begin{tabular}{cllccc}
\hline \multirow{2}{*}{ Strain } & & & & Doses $(\mathrm{mg} / \mathrm{kg} /$ day $)$ & 50 \\
\cline { 3 - 5 } & & & 0 & 5 & $3.36 \pm 0.18^{* *}$ \\
& Liver & $(\mathrm{g} / 100 \mathrm{~g})$ & $3.01 \pm 0.07$ & $3.16 \pm 0.23$ & $0.71 \pm 0.03$ \\
$\mathrm{n}$ SD & $(\mathrm{g} / 100 \mathrm{~g})$ & $0.65 \pm 0.07$ & $0.65 \pm 0.05$ & $0.17 \pm 0.04$ \\
& Kidney & $(\mathrm{g} / 100 \mathrm{~g})$ & $0.21 \pm 0.04$ & $0.19 \pm 0.04$ & $24.3 \pm 2.0$ \\
& Uterus & $(\mathrm{mg} / 100 \mathrm{~g})$ & $25.8 \pm 4.6$ & $24.3 \pm 4.2$ & $36.2 \pm 2.6$ \\
& Adrenal & $(\mathrm{mg} / 100 \mathrm{~g})$ & $30.4 \pm 5.8$ & $34.8 \pm 6.2$ & $6.1 \pm 0.9$ \\
& Ovary & $(\mathrm{mg} / 100 \mathrm{~g})$ & $5.5 \pm 0.5$ & $5.3 \pm 1.2$ & $3.02 \pm 0.15$ \\
& Hypophysis & $(\mathrm{g} / 100 \mathrm{~g})$ & $2.88 \pm 0.07$ & $2.97 \pm 0.16$ & $0.72 \pm 0.04$ \\
& Liver & $(\mathrm{g} / 100 \mathrm{~g})$ & $0.66 \pm 0.02$ & $0.70 \pm 0.04$ & $0.33 \pm 0.11$ \\
& Kidney & $(\mathrm{g} / 100 \mathrm{~g})$ & $0.31 \pm 0.10$ & $0.29 \pm 0.11$ & $30.5 \pm 3.1$ \\
& Uterus & $(\mathrm{mg} / 100 \mathrm{~g})$ & $26.6 \pm 3.0$ & $29.4 \pm 2.8$ & $38.6 \pm 4.6$ \\
& Adrenal & $(\mathrm{mg} / 100 \mathrm{~g})$ & $33.6 \pm 3.8$ & $35.7 \pm 4.2$ & $6.4 \pm 0.5$ \\
\hline & Ovary & $(\mathrm{mg} / 100 \mathrm{~g})$ & $6.3 \pm 1.2$ & $6.6 \pm 0.7$ & $4.04 \pm 0.15^{* *}$ \\
& Hypophysis & $(\mathrm{g} / 100 \mathrm{~g})$ & $3.57 \pm 0.17$ & $3.74 \pm 0.16$ & $0.68 \pm 0.04$ \\
& Liver & $(\mathrm{g} / 100 \mathrm{~g})$ & $0.67 \pm 0.03$ & $0.63 \pm 0.03$ & $0.20 \pm 0.03$ \\
& Kidney & $(\mathrm{g} / 100 \mathrm{~g})$ & $0.21 \pm 0.03$ & $0.22 \pm 0.04$ & $25.9 \pm 2.2$ \\
& Uterus & $(\mathrm{mg} / 100 \mathrm{~g})$ & $24.1 \pm 2.0$ & $24.6 \pm 3.6$ & $32.5 \pm 7.7$ \\
& Adrenal & $(\mathrm{mg} / 100 \mathrm{~g})$ & $33.7 \pm 3.3$ & $29.3 \pm 9.7$ & $5.7 \pm 1.5$
\end{tabular}

Mean \pm S.D.

**Significantly different from the control at $p<0.01$. 

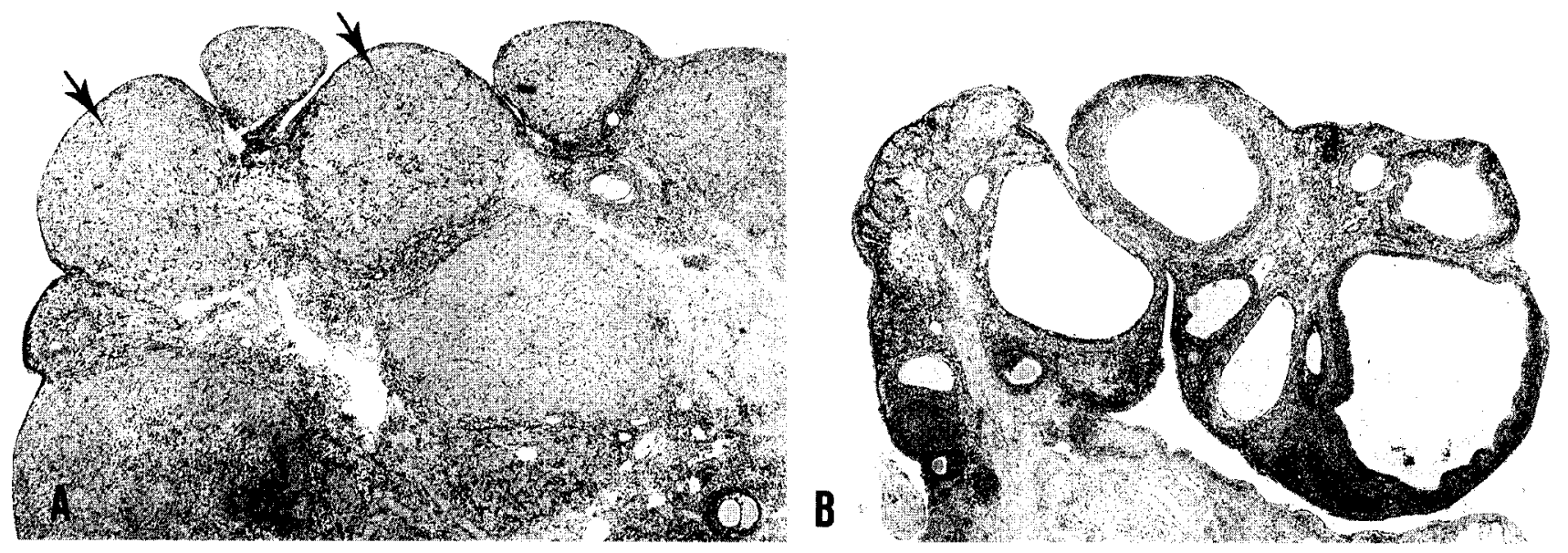

Fig. 1. A : A Donryu rat given $0 \mathrm{mg} / \mathrm{kg}$ atrazine. Corpora lutea (arrow) are clearly observed. HE, $\times 30.0 . \quad$ B : A Donryu rat showing persistent estrus in the $50 \mathrm{mg} / \mathrm{kg}$ atrazine group. Cystic enlargement of the follicles is predominant and corpora lutea are not observed. $\mathrm{HE}, \times 30.0$.

Table 7. BrdU Labeled Cells in the Endometrial Epithelium of Rats Dosed with Nonylphenol for 28 Days

\begin{tabular}{|c|c|c|c|}
\hline Strain & $\begin{array}{c}\text { Doses } \\
(\mathrm{mg} / \mathrm{kg} / \text { day })\end{array}$ & $\begin{array}{l}\text { No. of animals } \\
\text { examined }\end{array}$ & $\begin{array}{l}\text { No. of labeled } \\
\text { cells } / 1,000 \text { cells }\end{array}$ \\
\hline \multirow{3}{*}{ SD } & 0 & 6 & $\begin{array}{r}25.45 \\
\pm 16.66\end{array}$ \\
\hline & 60 & 6 & $\begin{array}{r}19.51 \\
+12.58\end{array}$ \\
\hline & $250-150^{\mathrm{a})}$ & 5 & $\begin{array}{r}23.80 \\
+23.08\end{array}$ \\
\hline \multirow{3}{*}{ F344 } & 0 & 6 & $\begin{array}{r}30.14 \\
\pm 32.21\end{array}$ \\
\hline & 60 & 6 & $\begin{array}{r}17.35 \\
\pm 21.10\end{array}$ \\
\hline & $250-150^{\mathrm{a})}$ & 6 & $\begin{array}{r}68.65 \\
\pm 54.75\end{array}$ \\
\hline \multirow{3}{*}{ Donryu } & 0 & 6 & $\begin{array}{r}19.77 \\
+12.96\end{array}$ \\
\hline & 60 & 6 & $\begin{array}{r}12.94 \\
+16.26\end{array}$ \\
\hline & $250-150^{\mathrm{a})}$ & 6 & $\begin{array}{r}23.17 \\
\pm 13.10\end{array}$ \\
\hline
\end{tabular}

Mean \pm S.D.

a) Dosed at a level of $250 \mathrm{mg} / \mathrm{kg}$ from days 1 to 4 of dosing and at $150 \mathrm{mg} / \mathrm{kg}$ thereafter.

same, and the rat strain used was also the same. Thus the lesion was considered to be accidental. Although only slight tendencies for increase in numbers of BrdU-positive cells, but not significant, were observed, it was limited to the high-dose nonylphenol group of F344 rats, and it is uncertain whether the result is meaningful or not. These results indicate that adult rats are less sensitive than immature or ovariectomized animals, since almost the same or higher dosage levels as for the studies using immature animals or ovariectomized animals were used in the nonylphenol treated groups of the present study in line with the previous reports $^{3,23}$. Uterine weight and epithelial cell-height may be less sensitive than vaginal smear for evaluation of estrogenic
Table 8. BrdU Labeled Cells in the Endometrial Epithelium of Rats Dosed with Atrazine for 28 Days

\begin{tabular}{|c|c|c|c|}
\hline Strain & $\begin{array}{c}\text { Doses } \\
(\mathrm{mg} / \mathrm{kg} / \text { day })\end{array}$ & $\begin{array}{l}\text { No. of animals } \\
\text { examined }\end{array}$ & $\begin{array}{l}\text { No. of labeled } \\
\text { cells } / 1,000 \text { cells }\end{array}$ \\
\hline \multirow{3}{*}{$\mathrm{SD}$} & 0 & 6 & $\begin{array}{r}16.29 \\
+20.53\end{array}$ \\
\hline & 5 & 6 & $\begin{array}{r}17.72 \\
\pm 13.60\end{array}$ \\
\hline & 50 & 6 & $\begin{array}{r}11.06 \\
+11.05\end{array}$ \\
\hline \multirow{3}{*}{ F344 } & 0 & 6 & $\begin{array}{r}17.30 \\
+18.50\end{array}$ \\
\hline & 5 & 6 & $\begin{array}{r}15.47 \\
\pm 11.16\end{array}$ \\
\hline & 50 & 6 & $\begin{array}{r}28.10 \\
\pm 27.69\end{array}$ \\
\hline \multirow{3}{*}{ Donryu } & 0 & 6 & $\begin{array}{r}15.79 \\
\pm 14.60\end{array}$ \\
\hline & 5 & $5^{\#}$ & $\begin{array}{r}11.29 \\
+15.96\end{array}$ \\
\hline & 50 & $5^{\#}$ & $\begin{array}{r}15.94 \\
+17.51\end{array}$ \\
\hline
\end{tabular}

Mean \pm S.D.

${ }^{\sharp}$ Excluding one animal each showing persistent estrus.

activity of chemicals, when adult animals are used for the study. In the previous 28-day toxicity study of nonylphenol ${ }^{25}$, no endocrine disrupting effects were detected because estrous cycle was not checked. Thus, examination of estrous cycle by vaginal smear is considered to be very useful for evaluation of estrogenic activity of chemicals in 28 day toxicity study. Further studies with other chemicals should be needed in these points of view. In the present study, nonylphenol was given orally, because the main exposure route in humans is oral. However, oral application might be less sensitive than intraperitoneal or subcutaneous ones because the latter eliminates direct effects of metabolism of the chemicals during first passage through the liver. 
Contrary to expectation, however, Donryu rats was not so sensitive, compared with F344 and SD rats, for detection of week estrogenic activity.

In the atrazine treated groups, persistent estrus was observed in F344 and Donryu Although many toxicokinetic data revealed strain difference in the biological effects of chemicals in rats ${ }^{16}$, strain difference was not observed in the present study, further studies with other chemicals being needed for rats. This might have also been considered to be effects of atrazine treatment, because it has been reported that atrazine causes disruption of estrous cyclicity in laboratory rats, increasing the day in estrus ${ }^{26}$, and there are no animals with persistent estrus in our background data in which these strains of animals were examined within 3 months of age. In addition, in Donryu rats, ovarian atrophy was observed in animals showing persistent estrus. In this strain of rats, the ovary weight decrease with age, and after 12 months of age it shows one-fourth the relative value observed at 1.5 months of age, although the relative weights remain almost constant in F344 rats after 6 months of age ${ }^{27}$. Atrazine is known to show anti-estrogenic effects via the pituitarygonadal axis ${ }^{28}$. These results indicate that atrazine might progress the development of agedependent ovarian atrophy in Donryu rats. It is very interesting that increase of $\mathrm{BrdU}$-positive cells in the uterine endometrial epithelium was obvious in rats with ovarian atrophy, because atrazine is reported to induce endometrial adenocarcinomas in rats ${ }^{29}$. However, the possibility that these findings are not related to atrazine-treatment, may remain, since persistent estrus and ovarian atrophy were seen only in each one animal of both 5 and $50 \mathrm{mg} / \mathrm{kg}$ groups, and there were also no dose-effect relations in ovarian weights and BrdU positive cells of these animals. Further studies using large numbers of animals and many doses of the chemicals should be needed to confirm the effect of atrazine.

In the present study, liver weights were affected in any strain of rat given nonylphenol or atrazine, along with kidney weights in F344 rats given nonylphenol. This is in line with the previous reports that two compounds induce hepatoand/or renal toxicity in rats ${ }^{25,30,31}$.

These results indicate that severe morphological effects might not be induced in female reproductive organs of adult rats by short-term exposure to these chemicals, because of homeostasis in animals, unless very high doses are given. Vaginal smear may be the most sensitive parameter for detection of estrogenic or anti-estrogenic effects of chemicals, when normal cycling animals are used for the study. On the other hand, putative endocrine disrupters with estrogenic or anti-estrogenic activities exist in very low concentrations in the environment, and mammals including humans might be exposed to these doses for long periods. However, the relation between exposed levels or periods and effects of these chemicals such as nonylphenol and atrazine is still ongoing debate.

In addition, fetus and newborn animals are considered to be more sensitive than adult ones. Thus, further longterm studies using low doses and/or immature animals are needed for risk evaluation of these chemicals in mammals including humans.

Acknowledgement : We would like to express our gratitude to Mitsui Chemical Co. Ltd. for providing the test chemical.

\section{References}

1. Colborn $\mathrm{T}$ and Clement $\mathrm{C}$. editors. Chemically induced alterations in sexual and functional development: the wildlife/ human connection. Princeton, NJ : Princeton Scientific Publishing. 1992.

2. Guillette LJ Jr, Crain DA, Rooney AA, and Pickford DB. Organization versus activation : the role of endocrine-disrupting contaminants (EDCs) during embryonic development in wildlife. Environ Health Perspect 1995; 103 (suppl7) : 157164.

3. Soto AM, Justicia H, Wray JW, and Sonnenschein C. pNonylphenol: an estrogenic xenobiotic released from "modified" polystyrene. Environ Health Perspective 1991; 92: 167-173.

4. Lech JJ, Lewis SK, and Ren LF. In vivo estrogenic activity of nonylphenol in rainbow trout. Fundam Appl Toxicol 1996; 30 : 229-232.

5. Danzo BJ. Environmental xenobiotics may disrupt normal endocrine function by interfering with the binding of physical ligands to steroid receptors and binding protein. Environ Health Perspect 1997; 105 (13): 294-301.

6. Tennant MK, Hill DS, and Eldridge JC. Possible antiestrogenic properties of chloro-s-triazine in rat uterus. J Toxicol Environ Health 1994; 43 : 183-196.

7. Connor K, Howell J, Chen I, Liu H, Berhane K, Sciarretta C, Safe S, and Zacharewski T. Failure of chloro-s-triazinederived compounds to induce estrogen receptor mediated responses in vivo and in vitro. Fundam Appl Toxicol 1996; 30: $93-101$

8. Tennant MK, Hill DS, and Eldridge JC. Chloro-s-triazine antagonism of estrogen action: limited interaction with estrogen receptor binding. J Toxicol Environ Health 1994; 43 : 197-211.

9. White R, Jobling S, Hoare SA, Sumpter JP, and Parker MG. Enviromentally persistent alkylphenolic compounds are estrogenic. Endocrinology 1994; 135: 175-182.

10. Gaido KW, Leonard LS, Lovell S, Gould JC, Babai D, Portier CJ, and McDonnell, DP. Evaluation of chemicals with endocrine modulating activity in a yeast-based steroid hormone receptor gene transcription assay. Toxicol Appl Pharmacol $1997 ; 143$ : 205-212

11. Maekawa A, Takahashi M, Ando J, and Yoshida M. Uterine carcinogenesis by chemicals/hormones in rodents. J Toxicol Pathol 1999; 12: 1-11.

12. Maekawa A and Yoshida A. Susceptibility of the female genital system to toxic substances. In: Pathobiology of the Aging Mouse (Vol. 1), U Mohr, DL Dungworth, CC Capen, WW Carlton, JP Sundberg, and JM Ward (eds), Washington DC : ILSI Press, 481-493, 1996.

13. Maekawa A. Genital tumors in female rats-influence of chemicals and/or hormones and host factors on their occurrence. J Toxicol Sci 1994; 19: 119-132.

14. Nagaoka $T$, Onodera $H$, Matsushima $Y$, Todate $A$, Shibutani $M$, Ogasawara $H$, and Maekawa $A$. Spontaneous uterine adenocarcinomas in aged rats and their relation to endocrine imbalance. Cancer Res Clin Oncol 1990; 116: 623-628.

15. Chapin RE, Stevens JT, Hughes CL, Kelce WR, Hess RA, and Daston GP. Symposium Overview. Endocrine Modulation of Reproduction. Fundam Appl Toxicol 1996; 29: [-17.

16. Ward SL and Newall DR. Factors underlying strain difference in retinoic acid-induced limb abnormalities in the AHA, RH and AP rat. Teratology 1990; $42: 23$.

17. Japanese Association for Laboratory Animal Science. Guidelines for animal experimentation. Exp Anim 1987; 36 : 285288.

18. Khochbin S, Chabanas A, Albert P, Albert J, and Lawrence JJ. Application of bromodeoxyuridine incorporation measure- 
ments to the determination of cell distribution with the $\mathrm{S}$ phase of the cell cycle. Cytometry 1988; 9: 499-503.

19. Dunnet $\mathrm{CW}$. New tables for multiple comparison with a control. $1964 ; 20: 482-491$

20. Branham WS, Sheeham DM, Zehr DR, Ridlon E, and Nelson CJ. The postnatal ontogeny of rat uterine glands and agerelated effects of $17 \beta$-estradiol. Endocrinology 1985; 117: 2229-2237.

21. Branham WS, Zehr DR, Chen JJ, and Sheehan DM. Alterations in developing rat uterine cell populations after neonatal exposure to estrogens and antiestrogens. Teratology 1988 ; 38: $271-279$.

22. Medlock KL, Branham WS, and Sheehan DM. The effects of phytoestrogens on neonatal rat uterine growth and development. Proc Soc Exp Bio Med 1995; 208 : 307-313.

23. Lee PC and Lee WC. In vivo estrogenic action of nonylphenol in immature female rats. Bull Environ Contam Toxicol $1996 ; 57: 341-348$.

24. Paris AL and Ramaley JA. Effects of short-term stress upon fertility, I. before puberty. Fert Steril 1973; 24: 540-545.

25. Okazaki S, Enami T, Nakamura H, Hatayama K, Tamura K, Numata $\mathrm{H}$, and Katsumata $\mathrm{T}$. Twenty-eight-day repeated dose oral toxicity test of nonylphenol in rats. In : Toxicity Testing Reports of Environmental Chemicals, Chemicals inves- tigation Promoting Council Vol 4, 753-764, 1996

26. Eldridge JC, Fleenor-Heyser DG, Extrom PC, Wetzel LT, Breekenridge CB, Gillis JH, Luempert LG, and Stevens JT. Short-term effects of chlorotriazines on estrus in female Sprague-Dawley and Fischer 344 rats. J Toxicol Environ Health $1994 ; 43$ : 155- 167.

27. Nagaoka T, Takeuchi M, Onodera H, Matsushima Y, AndoLu J, and Maekawa A. Sequental observation of spontaneous endometrial adenocarcinoma development in Donryu rats. Toxicol Pathol 1994; 22 : 261-269.

28. IARC. Atrazine. In: IARC Monographs on the Evaluation of Carcinogenic Risks for Humans (Vol. 53), Lyon: IARC, 441-466, 1991.

29. Pinter A, Torok G, Borzsiny M, Snrjan A, Lsik M, Kelecsimyi $Z$, and Kocgis $Z$. Long-term carcinogenicity bioassay of the herbicide atrazine in F344 rats. Neoplasia $1990 ; 37$ : 533544.

30. Santa Maria C, Vilas MG, Muriana FG, and Relimpio A. Subacute atrazine effects on rat renal function. Bull Environ Contam Toxicol 1986; 36: 325-331.

31. Santa Maria C, Mereno J, and Lepez-Campos JL. Hepatotoxicity induced by the herbicide atrazine in the rat. $\mathbf{J}$ Apll Toxicol 1987; $7: 373-378$. 